\title{
Impact of Salaries and Financial Incentives on Job Stability at Al-Basr International Foundation (Makkah Eye Hospital - Sudan)
}

\author{
Saad Mohamed Ahmed Ali, PhD \\ Assistant Professor \\ Department of Administrative Sciences \\ College of Community \\ Najran University \\ Najran - King Abdulaziz Road \\ Saudi Arabia
}

\begin{abstract}
Abstract: Employee stability is a very critical issue for organizations to retain their best talented, experienced, and skilled employees with them. Therefore, the aim of this paper is to investigate the relationship between salaries and financial incentives offered to employees and the employees' job stability. For this purpose, an empirical study was conducted in a Sudanese hospital. In this study deductive approach, analytical and descriptive methods were used. Data was largely collected with a questionnaire; interviews and observation were also used to confirm collected data. A simple closed-ended questionnaire divided into two sections, section (1) to collect demographic data about the sample population (gender, age, ..ect) and section (2) consist of 20 questions to help the respondent answering how strongly he/she agrees or disagree to each statement. The results of the empirical study show that there is a significant relationship between salaries and financial incentives and job stability. The findings suggest that offering adequate salaries and financial incentives can result in a better job stability, commitment and performance.
\end{abstract}

Keywords: salaries, financial incentives, job stability, employees, job security, employee retention.

\section{Introduction}

Today, job seekers are looking for work in organizations that offer satisfactory work conditions and stable jobs. These views of potential workforce raise several important concerns for organizations. Therefore, improving employee satisfaction has become one of the main corporate objectives in recent years (Garcia-Bernal et al., 2005). The job stability means job satisfaction and job security that drives employees to loyally work for the organization. Job stability can't be casually realized, but rather is a result of many factors and conditions organizations should provide to retain their competent employees who achieve their goals.

Therefore, specialists of human resources in organizations are concerned with the human element, starting from the right selection of competent employees, then endeavouring to secure the proper working conditions that lead to job stability and improve performance, and training those employees with more skills to carry out their work competently.

However, the ability to work alone is not sufficient for driving employees to work as efficiently as possible unless there is a motivation, as the efficiency depends on two basic elements, namely the ability to work and the desire to do it. The ability to work is usually represented by the employee's skills, knowledge and capabilities in addition to personal readiness to develop himself with more education and training. As for the desire to work, it is motivated by the employee's behavior in the direction that achieves the goals of the organization. The process of motivation is driven by external factors that encourage the employee to improve his performance. (Hamdan and Al-Saket: 2011).

Among the most important factors that create the desire to work is the financial compensation in forms of salaries, allowances, bonuses, incentives, etc., at sufficient levels that compete with the prevailing levels of compensations in similar organizations, besides the employees should have appropriate training and professional development according to an approved plan. And that the compensation system in any organization should be based on criterions of competence and level of achievement of goals. Also, the work environment should be appropriate to stimulate creativity and should be free of all kinds of administrative diseases that may threaten employees of losing their jobs or pushing them to quit their work for reasons other than incompetence or failure to achieve goals.

Several studies have shown that salaries and financial incentives are closely related to job stability, and that their adequacy and fairness can cultivate the spirit of enthusiasm and initiative among employees, and encourage them to maintain their work and improve their performance, which is reflected in the stability and outstanding performance of the organization as a whole. 
The methods of motivation evolved through several stages until they crystallized in the way they are today, so they started with the traditional phase in which the focus was on financial incentives only, then followed by the stage of human relations school, which concerned with moral incentives next to financial compensations, then came the modern stage that linked between both financial and moral incentives (Abuwalan, 2016)

The adequacy of salary and incentives in different organizations greatly affect the decisions of individuals to accept job offers and maintain good levels of performance in certain organizations or decide to quit their jobs in others, therefore it has become very necessary to pay attention to regularly restudy salaries and financial incentives and analyze their effects in order to modify and improve them when needed.

because job stability has become of great importance in the administrative process, which appears through the policies applied in organizations for stimulating and driving their staffs to work with vitality, activity and stability, and also to avoid any negative effects that job instability may cause such as frequent absence, delay, high turnover, dissatisfaction and lack of loyalty..etc, and from this standpoint the idea of this study developed by the researcher, which came under the title "The Impact of salaries and financial incentives on job stability in the Al-Basr International Foundation (Makkah Eye Hospital - Sudan)

\section{The Concept of Job Stability:}

Job stability means the fact of an employee, or a group of employees, being able to keep the same job for a long time and not changing job often (Cambridge dictionary), Job stability means the psychological state that reflects the employees' expectations about the extent of their continuity at work within the same company, it is the state of mind that the employee creates about the extent of his stability in his current job in the short term, and job stability arises as a result of the practices of the company's officials and its policies towards employees. Therefore job stability is not just about an employee ability to hold a job. It also means the employee will enjoy steady pay and benefits, and reduced stress levels (Sam Ashe-Edmunds). Not long time ago this was one of the crucial parameters in selecting a job; people chose stability over nature of work. That was the reason people sought government jobs. A stable job is not that one finds easily these days. Even people at the management holding key positions can't be secure of their jobs, if the shareholders are not happy with the way the company is functioning, the CEO might have to resign. Several conditions are considered for stability such as output from employees, satisfaction, economic growth of the country, growth of the company and the employee, productivity is one of the few (HR Dictionary). While job instability means the fear related to the position in an organization, such as deterioration of the work condition, low opportunities for career development, and gradual decreases in salary (Sverke\&Hellgren, 2002)

\section{The Importance of the Study:}

The importance of the research stems from the scarcity of studies that have been conducted on the impact of salaries and financial incentives on job stability, as most of the previous studies tend to focus on job satisfaction, organizational commitment and job performance. And the insisting need for private and public organizations to achieve job stability in order to be able to face the rapid changes and competition in the local and external environment in light of the prevailing economic changes. The importance of this study also emerges from the theoretical and intellectual implications of this study, which represent a real response to one of the main issues and challenges facing the human element in the organizations of Sudan. The importance of this research also stems from the recognition of the importance of the following:

1)Financial compensation and how to deal with in a way that helps in enhancing the job stability of employees.

2) The effect of financial compensation on the stability of employees in private organizations.

\section{Problem Statement}

Under intense competition nowadays, considering the economic situation in Sudan now which is very appalling as many experts have predicted that the current economic situation may take long time to recover. Hence, this economic situation will certainly affect job security. Job security is something positive about work while job insecurity is something negative about work and it will affect a person's life inside and outside work. While, many private sector organizations have become unable to retain their best talent with them, which negatively affects the work stability and effectiveness of performance in general. Therefore, this study addresses the problem of job instability associated with salaries and financial incentives in private organizations, taking Makkah Eye Hospitals in Sudan as a model for the rest of private organizations, In addition, the research problem can be represented in the form of the following questions:

1)Is there a statistical relationship between the adequacy of salaries and wages represented in (daily, weekly, and monthly wages and monthly salaries) and job stability represented by (job satisfaction and job commitment)?

2) Is there a statistical relationship between the adequacy and fairness of financial incentives represented in (periodic and performance-related incentives) and job stability represented in (job satisfaction and job commitment)? 


\section{Hypothesis:}

This study seeks to verify the following hypotheses:

1)There is a relationship between adequacy of wages and salaries, improvement of the living conditions, and the job stability.

2) There is a relationship between adequacy and fairness of financial incentives and the job stability.

\section{Literature Review:}

Several studies have been carried out to investigate the effect of financial compensation, including wages, salaries, and financial incentives, on job stability in public and private organizations, including the following; Darwish Youssef (1998) studied the satisfaction about job security as a determinant of organizational commitment and job performance in a multicultural work environment, his study concluded that job satisfaction is closely related to both organizational commitment and job performance.

Jay Stewart (2002) also investigated the recent trends in job stability and job security: evidence from the current population survey - March 2002, his study aimed to answer the question of whether job stability and job security decreased in the period from 1980 to 1990 in the United States. Alfonso Souza-Bouza (2004) also studied job stability and job security: a comparative study on Switzerland's experience in the 1990s, the study aimed to casts doubts on the extent to which exposure to globalization can influence job instability. ArifAl Aljurayd(2007) investigated the motivation and its role in achieving job satisfaction for employees in the Al-JoufArea police in the Kingdom of Saudi Arabia. Miikka Rokkanen et al (2010), investigated Changes in Job Stability using lifetime job histories from the pension records to evaluate changes in job stability in Finland between 1963 and 2004. Al-Fares (2011) studied the effect of motivation policies on organizational loyalty in public institutions, his study aimed to clarify both the concepts of incentive policies and organizational loyalty and to explain the relationship between motivation and organizational loyalty policies. Ghazi Hassan (2013) investigated the effect of incentives on improving performance among workers in public sector institutions in Jordan. The research problem stemmed from indications of the insufficiency in the systems and methods of incentives provided to employees.

This study highlighted the importance of incentives as one of the most prominent issues and challenges facing the human resource. Bakan Ismail et al (2013), studied the relationship between employees' income level and employee job satisfaction, the aim of their study was to investigate the relationship between employees' income level and employees' job satisfaction. Gerrit JM Treuren, et al, (2014) investigated the impact of pay understanding on pay satisfaction and retention: Salary sacrifice understanding in the not-for-profit sector, their focus was on examining the impact of employee understanding of components of their pay system on pay satisfaction and leaving intentions for a poorly paid occupational group. Mathebula et al, (2015) discussed and assessed if causes of job insecurity in the construction industry, their study contributes to the body of knowledge on the subject of job insecurity in the construction industry. Ahmad Al-Hazaimeh (2016), investigated the effect of incentives on occupational stability in the public sector from the view point of employees at the Ministry of Interior (MI) in Jordan. Bodjrenou Kossivi1, et al (2016) investigated the determining factors of employee Retention, their focus was on reviewing the findings of previous studies conducted by various researchers with the aim to identify determinants factors of employee retention. Noraishah Bt Daud(2017) conducted a study on job security and wellbeing among private workers in Malaysia, the objectives of her study was to look at the relationship between job security and well-being of workers. Shuja Iqbal et al, (2017) investigated the relationship between job satisfaction, organization culture, benefits and salary to check their influence on employee retention, the aim of their study was to measure the relatedness of these variables with the motivational theories. Lee, Chun-Chang, et al, (2017) investigated the effects of salary structure, performance requirements, and type of business on the performance of housing agents, including base pay, individual bonuses, and group bonuses and type of business.

\section{Methodology \& Methods}

\section{Population and sample:}

The population of the study was the workers of the Makkah Eye Hospitals-Sudan (head quarter) as a model for the rest of similar organizations. The number of the employees is (90) males and females employees. A random sample was selected that consisted of (50) employees working in. Three levels of employees (department managers, operational supervisors, and general staff) were surveyed with a survey instrument.

\section{Context of the study:}

The study is primarily based on the descriptive approach. It also depends on the review of the literature regarding Impact of salaries and financial incentives on job stability used as secondary sources such as books, references, and records to collect the necessary data for the theoretical part of the study. As for the analytical part of the study, the primary sources such as questionnaires and observations were used. 


\section{Data Collection and Analysis}

The survey instrument (the questionnaire) is consisted of two sections: section I: focused on personal data of the study sample (gender, age, academic qualification, specialty, years of experience\& career level).Section II: consisted of 20 questions based on the impact of salaries and financial incentives on the job stability to be answered according to the Likert 5 scale, which includes five levels (strongly agree, agree, agree to some extent, disagree, strongly disagree). The questionnaire's paragraphs stability was tested according to the methods of Cranach's Alpha. And the consistency was found 0.94. The survey instrument was handed out to the 60 randomly selected managers, supervisors and employees of the study sample and 50 questionnaires were recovered (recovery rate of $83 \%)$.

The data were evacuated into tables especially prepared for the purpose of data analysis, and probabilities of 0.05 were considered significant. Demographics data (gender, age, academic qualification, specialty, years of experience, and career level) were designated as independent variables. The dependent variables were the statements of the impact of salaries and financial incentives on the job stability. Data were analyzed using Pearson's chi-square test of (SPSS) Statistical Package for Social Sciences, to show the nominal relationships/associations between gender, age, academic qualification, specialty, years of experience, \& career level) and the impact of salaries and financial incentives.

\section{Sample profile}

Of the 60 questionnaires distributed, 50 were completed and returned, a response rate of $83 \%$. The sample of 50 respondents consisted of $28 \%$ female and $72 \%$ male employees, all were full-time employees. When grouped by age $54 \%$ were $<30$ years old, $32 \%$ were from 30 to less than 40 years, $14 \%$ were from 40 years and above. The subjects of the study sample hold a bachelor (42\%), 16\% hold master degree, 30\% hold intermediate diploma, $2 \%$ hold $\mathrm{Ph} . \mathrm{D}$ degree, $10 \%$ holda secondary certificate. The specialties of respondents surveyed were $34 \%$ administrative, $62 \%$ medical, $4 \%$ were from various disciplines. The experience of most of the respondents (46\%) is less than 5 years; from 5 to 10 years $(32 \%)$ and those with the least experience from 10 years and abovewere $22 \%$. The medical and administrative employees were the major career (86\%), followed by supervisors $(6 \%)$ section managers $(6 \%)$, department managers (2\%), as detailed in table (1).

\section{Results}

This part discusses the results of this study and its findings in light of previous relevant research and provides its recommendations for human resource and executive managers, and employees work in Makkah Eye Hospitals and similar organizations.

When reading table (2)we are interested in the results of the "Pearson Chi-Square" columns. We can see in all categories/columns that $\mathrm{P}$ : value for most statements $>0.05$ This tells us that there is no statistically significant association between respondents (gender, age, academic qualification, specialty, experience \& position) and their answers to statements and this should not be a cause for concern, except the followings;

In the respondent age column we can see that $P$ : value for most statements $>0.05$ except statement no (8) for which $\mathrm{p}$ : value $=(0.012)$ which shows statistically significant association between respondents age and their answers. This statement realized in favor of those who strongly disagree, but the significance can be attributed to opinions of both males and females who agree with the statement and see themselves and some of their colleagues really don't look for another paid work to do besides their current jobs.

In respondent academic qualification column $\mathrm{p}$ : value for all statements $>0.05$, except statement no $(5,6)$ for which $\mathrm{p}$ : value $<0.05$ which shows statistically significant association between respondents academic qualification and their answers. Both statements were realized in favor of those who strongly disagree, but the significance can be attributed to opinions of both males and females who agree with the statements and see that their salaries are sufficient to save part of them to achieve some of their future goals. In respondent specialty column p: value for all statements $>0.05$, except statement no (6) for which $\mathrm{p}$ : value $=(0.022)$ which shows statistically significant association between respondents specialty and their answers. This statement realized in favor of those who strongly disagree, but the significance can be attributed to opinions of both males and females who agree with the statement and see that their salaries are sufficient to overcome the worry about the future.

In respondent experience column p: value for all statements $>0.05$, except statement no (2) for which $\mathrm{p}$ : value $=(0.013)$ which shows statistically significant association between respondents specialty and their answers. This statement realized in favor of those who disagree, but the significance can be attributed to opinions of both males and females who agree with the statement and see that their salaries suit their qualifications and experiences. 


\section{Discussion}

The findings of this study emphasized the impact of salaries and financial incentives on job stability. Furthermore, the findings revealed a consensus among the surveyed staff's sample that adequate salaries and financial incentives have a positive impact on job stability and job security. There is also an agreement, among the field writers, and as seen from the literature review on the impact of employees 'adequate income represented in salaries and financial incentives on organizational loyalty, organizational commitment, job satisfaction and job performance.

According to this study salaries and financial incentives are positively related to job stability and job security. This is due to the fact that adequate and fair salaries and financial incentives lead to job stability. This study empirically established evidence for the existence of positive relationship between the adequate and fair salaries and financial incentives and the job stability; including; adequacy of salaries, incentives, in-service and after service benefits and services. Andas seen from the results this study finds that most of the surveyed staffs are not financially satisfied and think of changing their jobs because the provided salaries and financial incentives are insufficient. This finding agrees with the results of a study conducted byGhazi Hassan (2013) on the impact of incentives on improving the performance among workers in the public sector institutions in Jordan, where his study has revealed that provided financial incentives are insufficient and should be based on performance level. This finding also agrees with the results of another study conducted by Bakan Ismail et al (2013), on the relationship between employees' income level and employee job satisfaction where their study has revealed that employees with high income levels reported significantly higher levels of satisfaction than did employees with low-income levels.

The study also shows that although provided salaries are not sufficient to meet the cost of living, employees are still holding their jobs. This means that organizations should improve their provided salaries to meet the needs of employees in order to retain their best talent with them. This finding agrees with the results of Noraishah Bt Daud (2017) which analyzed the job security and well-being among private workers in Malaysia, where her study has revealed that employees have a high level of job security even in a desperate state. This finding also agrees with the results of study conducted by Bakan Ismail et al (2013), on the relationship between employees' income level and employee job satisfaction where their study has revealed that employees may have reported higher levels of satisfaction perhaps because they are motivated by receiving high income for their job effort. This finding also agrees with the results of study conducted by Arif Al Aljurayd (2007) on the motivation and its role in achieving job satisfaction for employees in the Al-Jouf Area police in the Kingdom of Saudi Arabia, where his study showed that the more financial and moral incentives the more job satisfaction. It also agrees with study conducted by Gerrit JM Treuren, et al, (2014) on the impact of pay understanding on pay satisfaction and retention, where their study showed that organizations may be able to improve the pay satisfaction of their employees and reduce employee turnover intention simply by improving their pay communication approaches.

This study also revealed that non-remunerative incentives make employee less loyal and uncommitted to their work. This means that provided financial incentives should be fair and rewarding to keep loyal employees. This finding is in agreement with the results of the study conducted by Shuja Iqbal et al,(2017) about the effects of job organizational culture, benefits, salary on job satisfaction ultimately affecting employee retention where their study has revealed a significant relationship between rewards offered by a firm and employee satisfaction for the employees to work for the organizations for longer time duration, they showed that high level of pay and benefits as compared to other companies in the market, attract and retain high-quality employees. This finding also agrees with the results of astudy conducted by Ahmad Al-Hazaimeh (2016), on the effect of incentives on occupational stability in the public sector where his study has revealed that the different kinds of incentives have an effect on the occupational stability process, also affect the occupational performance.

The findings of this study suggest that organizations need to understand the impact of salaries and financial incentives on job stability in order to increase their employees' job loyalty, and to manage turnover, intention to quit and absenteeism as the correlates of lower salaries and incentives.

\section{Conclusions and Recommendations}

The conclusion to be drawn from this study is that competitive salaries and financial incentives are very essential for job stability in organizations. Therefore, the quest of the researcher, as indicated in the title of the research, for a relationship between adequate salaries and financial incentives and the job stability is met.

Based on the results of research and discussion that have been described in the previous paragraphs and with reference to some theories and results of previous research, pertaining to this research, the following recommendations are the contribution of this study:

1. Organizations should restudy their offered salaries and financial incentives as needed especially when new economic policies and procedures are adopted in the country, in order to meet the cost of living and ensure the continuity of staff motivation. 
2. Salaries should be adequate, based on qualifications, experiences and the nature of work in order to stimulate competent employees.

3. Financial incentives should be remunerative and fairly distributed among employees based on efficiency, effectiveness and outstanding performance.

4. Provided or supported services should also be restudied when new economic changes happen in the country in order to keep satisfied and stable employees.

5. After service benefits should be stimulating to help employees guaranteeing their future after optional or compulsory retirement.

6. The need for management to have a clear policy for improving employee satisfaction, taking into consideration the needs of employees so they excel and feel secured and stable.

7. Management needs to have a good motivation system and clear performance measures to ensure the achievement of organization goals and provide suitable financial incentives.

\section{Acknowledgements}

Thanks to the research and development unit of Makkah Eye Hospitals-Sudan and their Staff who agreed to participate in this study.

Table (1). Characteristics of the surveyed sample (frequencies)

Graph (1) Assumption of responses on statements (\%)

\begin{tabular}{|c|c|c|c|}
\hline \multicolumn{2}{|l|}{ Category } & \multirow{2}{*}{\begin{tabular}{|l} 
Frequency \\
36
\end{tabular}} & \multirow{2}{*}{\begin{tabular}{|l} 
Percent \\
72
\end{tabular}} \\
\hline Gender & male & & \\
\hline & female & 14 & 28 \\
\hline & Total & 50 & 100.0 \\
\hline \multirow{4}{*}{ Age } & $<30$ years old & 27 & 54 \\
\hline & from 30 to less than 40 years & 16 & 32 \\
\hline & from 40 years and above & 7 & 14 \\
\hline & Total & 50 & 100.0 \\
\hline \multirow{6}{*}{ Academic Qualification } & secondary certificate & 5 & 10 \\
\hline & intermediate diploma & 15 & 30 \\
\hline & bachelor degree & 21 & 42 \\
\hline & master degree & 8 & 16 \\
\hline & $\mathrm{PhD}$ degree & 1 & 2 \\
\hline & Total & 50 & 100.0 \\
\hline \multirow{4}{*}{ Specialty } & Administrative & 17 & 34 \\
\hline & Medical & 31 & 62 \\
\hline & others & 2 & 4 \\
\hline & Total & 50 & 100.0 \\
\hline \multirow{4}{*}{ Years of experience } & Equal or less than 5 years & 23 & 46 \\
\hline & from 5 to less than 10 years & 16 & 32 \\
\hline & 10 years and above & 11 & 22 \\
\hline & Total & 50 & 100.0 \\
\hline \multirow{5}{*}{ Position } & directorate managers & 1 & 2 \\
\hline & department managers & 3 & 6 \\
\hline & Supervisors & 3 & 6 \\
\hline & Employees & 43 & 86 \\
\hline & Total & 50 & 100.0 \\
\hline
\end{tabular}


Table (2) Items Statistics:

\begin{tabular}{|c|c|c|c|c|c|c|c|c|}
\hline \multirow[t]{2}{*}{ Statements } & \multicolumn{8}{|c|}{ Media Interpreta Pearson Chi- Square (Asymp. Sig. (2-sided) } \\
\hline & n & & Gender) & Age & $\begin{array}{l}\text { A. } \\
\text { Qualif }\end{array}$ & & $\begin{array}{l}\text { Y. } \\
\text { Experie } \\
\text { nce }\end{array}$ & Positi \\
\hline $\begin{array}{l}\text { (1) The hospital administration increases salaries } 50 \\
\text { when new economic changes happen }\end{array}$ & 3.0 & $\begin{array}{l}\text { Agree to } \\
\text { some } \\
\text { extent }\end{array}$ & 0.822 & 0.058 & 0.633 & 0.741 & 0.219 & 0.917 \\
\hline \begin{tabular}{|l} 
(2) My salary suits and based on my50 \\
qualifications and experiences
\end{tabular} & 4.0 & Disagree & 0.165 & 0.289 & 0.109 & 0.267 & 0.013 & 0.620 \\
\hline $\begin{array}{l}\text { (3) My salary is adequate for the work I do and } 50 \\
\text { the effort I exert. }\end{array}$ & 4.0 & $\begin{array}{l}\text { Strongly } \\
\text { Disagree }\end{array}$ & 0.530 & 0.098 & 0.355 & 0.156 & 0.592 & 0.471 \\
\hline $\begin{array}{l}\text { (4) My salary is sufficient to meet the cost of } 50 \\
\text { living }\end{array}$ & 4.0 & $\begin{array}{l}\text { Strongly } \\
\text { Disagree }\end{array}$ & 0.304 & 0.536 & 0.021 & 0.603 & 0.205 & 0.400 \\
\hline $\begin{array}{l}\text { (5) I can save part of my salary to achieve some } 50 \\
\text { of my future goals }\end{array}$ & 4.0 & $\begin{array}{l}\text { Strongly } \\
\text { Disagree }\end{array}$ & 0.343 & 0.100 & 0.000 & 0.696 & 0.230 & 0.423 \\
\hline $\begin{array}{l}\text { (6) My salary is sufficient to overcome the worry } 50 \\
\text { about the future }\end{array}$ & 4.0 & $\begin{array}{l}\text { Strongly } \\
\text { Disagree }\end{array}$ & 0.203 & 0.957 & 0.035 & 0.022 & 0.904 & 0.555 \\
\hline \begin{tabular}{|l} 
(7) My salary is adequate, which reflects 50 \\
positively on my performance
\end{tabular} & 4.0 & Disagree & 0.128 & 0.555 & 0.441 & 0.212 & 0.298 & 0.738 \\
\hline $\begin{array}{l}\text { (8) I don't look for another paid work to do } 50 \\
\text { beside my current job. }\end{array}$ & 4.0 & $\begin{array}{l}\text { Strongly } \\
\text { Disagree }\end{array}$ & 0.256 & 0.012 & 0.055 & 0.132 & 0.199 & 0.461 \\
\hline $\begin{array}{l}\text { (9) I don't think of moving from my current job } 50 \\
\text { to another better paid job }\end{array}$ & 4.0 & \begin{tabular}{|l|l|} 
Strongly \\
Disagree
\end{tabular} & 0.943 & 0.206 & 0.000 & 0.469 & 0.572 & 0.709 \\
\hline $\begin{array}{l}\text { (10) I think of keeping my current job even if my50 } \\
\text { salary not increased }\end{array}$ & 3.50 & $\begin{array}{l}\text { Agree to } \\
\text { some } \\
\text { extent }\end{array}$ & 0.686 & 0.940 & 0.446 & 0.422 & 0.186 & 0.538 \\
\hline $\begin{array}{l}\text { (11) The hospital administration always motivates } 50 \\
\text { and reward outstanding performance }\end{array}$ & 3.0 & $\begin{array}{l}\text { Agree to } \\
\text { some } \\
\text { extent }\end{array}$ & 0.542 & 0.899 & 0.245 & 0.852 & 0.885 & 0.828 \\
\hline $\begin{array}{l}\text { (12) Rewards in the Hospital are based on } 50 \\
\text { efficiency and effectiveness. }\end{array}$ & 4.0 & Disagree & 0.711 & 0.284 & 0.842 & 0.744 & 0.194 & 0.675 \\
\hline \begin{tabular}{|l} 
(13) I believe financial incentives are fairly 50 \\
distributed among those who deserve them
\end{tabular} & 4.0 & Disagree & 0.677 & 0.403 & 0.273 & 0.143 & 0.301 & 0.751 \\
\hline $\begin{array}{l}\text { (14) The provided financial incentives are } 50 \\
\text { remunerative and make me more serious and } \\
\text { committed to work }\end{array}$ & 4.0 & Disagree & 0.307 & 0.756 & 0.719 & 0.314 & 0.506 & 0.872 \\
\hline $\begin{array}{l}\text { (15) The provided financial incentives inspire me } 50 \\
\text { for more development and creativity }\end{array}$ & 3.0 & Disagree & 0.777 & 0.713 & 0.670 & 0.786 & 0.432 & 0.773 \\
\hline $\begin{array}{l}\text { (16)I feel my performance is appreciated as a } 50 \\
\text { result of provided financial incentives }\end{array}$ & 4.0 & Disagree & 0.412 & 0.600 & 0.428 & 0.555 & 0.441 & 0.416 \\
\hline $\begin{array}{l}\text { (17) The services provided or supported by the } 50 \\
\text { Hospital meets my needs }\end{array}$ & 4.0 & $\begin{array}{l}\text { Agree to } \\
\text { some } \\
\text { extent }\end{array}$ & 0.059 & 0.436 & 0.144 & 0.242 & 0.248 & 0.641 \\
\hline \begin{tabular}{|l} 
(18) The provided allowances and financial 50 \\
benefits make me more loyal to the Hospital
\end{tabular} & 3.0 & Disagree & 0.319 & 0.729 & 0.095 & 0.142 & 0.394 & 0.755 \\
\hline $\begin{array}{l}\text { (19) After service benefits are stimulating and } 50 \\
\text { guarantee the future }\end{array}$ & 3.50 & $\begin{array}{l}\text { Strongly } \\
\text { Disagree }\end{array}$ & 0.416 & 0.561 & 0.159 & 0.473 & 0.442 & 0.681 \\
\hline $\begin{array}{l}\text { (20) I feel stable as a result of the financial } 50 \\
\text { benefits provided to me. }\end{array}$ & 4.0 & Disagree & 0.294 & 0.793 & 0.052 & 0.354 & 0.122 & 0.452 \\
\hline
\end{tabular}

\section{References}

HamdanRawan, Al-SaketYasmine, Motivation and its impact on the organizational loyalty of individuals working in government institutions, An-Najah National University, College of Economy, administrative science department, Pp. 4, 2011 
Abuwalan Khalid, The Impact of Financial and Nonfinancial Incentives On Performance of Employees in Palestinian Beverage Companies, Hebron University, College of Postgraduate studies, Business Administrative program, Pp. 3, 2016

Darwish Abdulrahman Yousef, Satisfaction with Job Security as a Predictor of Organizational Commitment and Job Performance in a Multicultural Environment, International Journal of Manpower 19(3):184-194 • May 1998

Ismail Bakan, Tuba Buyukbese, The Relationship between Employees' Income Level and Employee Job Satisfaction: An Empirical Study, International Journal of Business and Social Science, Vol. 4 No. 7; Pp. 18-25, July 2013

Jay Stewart, Recent Trends in Job Stability and Job Security: Evidence from the March CPS, U.S. DEPARTMENT OF LABOR, Bureau of Labor Statistics, Working Paper 356, Pp.1-30, February 25, 2002

Alfonso Sousa-Poza, Job Stability and Job Security: A Comparative Perspective on Switzerland's Experience in the1990s, European Journal of Industrial Relations, pp 31-49, Volume 10 Number 2004

MiikkaRokkanen, RoopeUusitalo, Changes in Job Stability: Evidence from Lifetime Job Histories, IZA Discussion Paper No. 4721, Pp. 1-39, January 2010

Arif Bin Matel Al Aljurayd,Motivation and its role in achieving job satisfaction for employees at Aljouf Area Police, Naif Arab University for Security sciences, college of Graduate studies Administrative sciences dept. Published Research 2007/04/25

Suleiman Alfares, the effect of motivation policies on organizational loyalty in public institutions, Journal of Damascus University for Economic and Legal Sciences - Volume 27 - First Issue, Pp. 69-91, 2011

Ghazi Hassan Al-Halaybeh, The impact of incentives on improving the performance of the employees in the Public Sector institutions In Jordan. Middle East University, College of business, published research 2013.

Ahmad Saleh Al-Hazaimeh, Effect of Incentives on Occupational Stability in the Public Sector " : Case Study on the Employees at the Ministry of Interior/Jordan, International Journal in Management and Social Science,Vol.04 Issue-12, (December, 2016), Pp. 82-102

NoraishahBtDaud, job security and well-being among private workers in Malaysia, Journal of Technology Management and Business, Vol 04, No 01, 2017, Pp. 25-38

Cambridge Online Dictionary, meaning of job stability. Retrieved from: https://dictionary.cambridge.org/dictionary/english/job-stability

Ashe-Edmunds, Sam. "Is Job Stability Important When Looking for a Company?" Retrieved from: Work Chron.com, http://work.chron.com/job-stability-important-looking-company-3186.html.

Human Resources Dictionary, Definition: Job Stability. Retrieved from: https://www.mbaskool.com/businessconcepts/human-resources-hr-terms/16945-job-stability.html

Hellgren, J., Sverke, M., \& Isaksson, K. (1999). A two-dimensional approach to job insecurity: Consequences for employee attitudes and well-being. European Journal of Work and Organization Psychology, 8, 179-195.

Shuja Iqbal, Li Guohao and Shamim Akhtar, Effects of Job Organizational Culture, Benefits, Salary on Job Satisfaction Ultimately Affecting Employee Retention, Review of Public Administration Management 2017, Volume 5, Issue 3, Pp. 2-7

LeratoMathebulaa, MulengaMukukab, Clinton Aigbavboac, and Wellington Thwalad, A theoretical assessment of causes of job insecurity in the construction industry, OTMC 2015 Conference, Pp. 1-6

Lee, Chun-Chang.Lee, Chia-Wei.Jiang, Liang-Ting.Lin, Chi-Yi. Huang, Fang-Lin. Yu, Cheng, (2017) The Impact of Salary Structure, Performance Requirements, and Type of Business on the Performance of Housing Brokerage Employees, Asian Economic and Financial Review, 2017, 7 (7): 685-699

BodjrenouKossivi, Ming Xu, BombomaKalgora, (2016) Study on Determining Factors of Employee Retention, Open Journal of Social Sciences, 4, 261-268

Gerrit JM Treuren, Gerrit JM Treuren, (2013) The impact of pay understanding on pay satisfaction and retention: Salary sacrifice understanding in the not-for-profit sector, Journal of Industrial Relations, (2014) Volume: 56 issue: 1 , page(s): $103-122$

Garcia-Bernal, J., Gargallo-Castel, A., Marzo-Navarro, M. and Rivera-Torres, Pilar. (2005). Job satisfaction: empirical evidence of gender differences. Women in Management Review, 20(4): 279-288. 